\title{
“IMAGINE YOURSELF” BEING A DIGNIFIED NATION: A PRELIMINARY ASSESMENT
}

\author{
I.G. Krisnadi ${ }^{1}$
}

\begin{abstract}
This paper is constructed in thepurposeto identify the J avaneselocal wisdom in order to develop a dignified Indonesian nation. Discussion on this paper will cover several issues as follows: identification of the Javanese local wisdom of the previous era, the broken down of society order due to Western culture penetration, and cultural strategy for the purpose of developing a dignified Indonesia.Success in identifying the J avanese local wisdom and causal factors of the J avanese society disorder, as well as the way out of kalabendu era, can be used as references to form cultural strategies in order to develop the dignified Indonesia. Thecultural strategies mentioned areasfollows: national repentance (National Reconciliation), law enforcement, the clean, honest, impartial and prestigious government's implementation, cultural movement of corruption eradication, inistilling the sense to value the domestic products and proud to be Indonesian, instilling the culture of being ashamed of doing something improper, science and technology development based on well-mannered, law, and humanity norms, and build social ethos based on religion.
\end{abstract}

Key words: dignified Indonesia, local wisdom, Western culturepenetration cultural strategies, kalabendu, national repentance, national reconciliation, corruption, well-mannered norm, law supreme, culture of being ashamed, social ethos.

\section{Introduction}

The definition of nasionalism as nationality concept was introduced by Ernest Renan in his speech on Dies (1882) entitled "Qu'est ce qu'une nation?" (What is nation?). According to Ernest Renan, nation is a giant formation of solidarity due to undergo one history altogether and an explicit expectation of living together as mutual (le desir de vivre ensemble?). Therefore, it is not the culture, language, religion or boundaries among countries that form a nation (Renan, 1994: 53-54). Similar thought was delivered by Otto Bauer stated that nation is the contingent of behaviors occurred from the affairs undergo by the citizen(Soekarno, 1964: 3).

1 IG. Krisnadi is a lecturer in the Department of History, Faculty of Arts, Universitas Jember. This Article has been reviewed by Prof. Bambang Purwanto (Gadjah Mada University), Dr. Nana Supriatna, M.Ed (Indonesia University of Education, and Dr. Agus Mulyana, M.Hum (Indonesia University of Education). 
Meanwhile, Taufik Abdullah assumes that "nation" as a "construction" resulted from a championed vision, and it is not the destiny. Similarly, Indonesian nation is not merely formed by nature, but as the result of struggling in the throes of history (Abdullah, 2001: 49).

According to Hans Kohn, in the context of nation, the highest fidelity of every individu is surrender to the nation (Khon, 1984). The realizations of the context are shown by the spirit to defend the country, and the conviction toward safety and integrity of the nation. Besides, they have a deep feeling about the bond toward the homeland as well as the traditions (Khon, 1984). The wealth homeland created pride that encourage feeling of unwilling if there is a party that disfigure and take it away. In this case, Western people as Portuguese, Spainnish, British, Dutch, and J apanese who had colonized are considered as enemies. However, J ohn Milton sees the concept of nation is not only merely a battle for collective freedom of suppression from other nations, but also for individual independence from political, social and cultural controls (Khon, 1984). Therefore, everything that may undermine nation identity and harm people's nationality are assumed as enemies to the nation, hence must be overcame immediately for the unity of the nation as well as the dignified nation.

Benedict Anderson, in the concept of nation affirmed that a nation is formed when all citizens conceive themselves as part of the community that have been imagined, rather than direct interaction among citizens in daily life. Citizen will never directly know, meet, or listen to all community members. Nevertheless, they have identified theirselves in their mind as part of the same nation with national symbol and identity as: basic state, national language, national anthem, national heroes, national films, and various national cultural expressions(Anderson, 2006).

The swift of Globalization wave has obscured the definition of territorial boundaries. Challenges to imagine you as a nation may face various threats and constraints. In this globalized era, there are influences from foreign cultures for it is assumed may raise their prestige as well as promising of hopes and dreams of amenities, advancement and prosperity. The concept of nationalism is vanished, so that the citizens will notimagine and put the highest loyalty to thestatesupreme in various forms of expression.

Globalization has affected erosion of theconcept of nationalism thataggravated the crisis in Indonesia. The term of crisis appeared in the end of Soeharto's reign in early 1998 that failed to cope with the international monetary crisis (krismon in Bahasa Indonesia). The powerlessness to overcome the monetary crisis had affected public economy that causing crisis in people's trust toward Soeharto's reign. Eventually, on May 21st, 1998, President Soeharto stepped down from his reign that had been carried for more than 30 years. Ever since the end of the repressivereign of Soeharto, reformation, with theissue of openness, had revealed the "hideout" of corruptors who have penetrated every aspect of life indicating Indonesia was under the condition of moral crisis that affect its dignity.

Theheavyduty carried by thegovernmentand Indonesian citizensarefinalizing the moral crisis and developing Indonesia as dignified nation. As the realization of 
the mandate, it is hoped that government, law enforcement, legislative, religious leaders and whole Indonesian citizen are required to purely and sincerely work harder and hand in hand one another. However, the government has not yet shown their seriousness in realizing the mandate of the people's suffering. The government that should hardly work to increase social welfare, in fact, has conspired with the law enforcement, legislator, or businessmen for their own, personally, or party's benefit. Corruption has spread out in every sector of living, even more; law has become commodity of trading. Despite efforts to eliminate corruptions have been attempted, but, in fact, it has not achieved optimal result, since the implementation has been selectively run. Besides, the Corruption Eradication Commission (KPK) has been ineffective.

Based in several concepts of nation, I assumethat crisis period in Indonesia at themomentcan behandled by exploringlocal wisdom of archipelago andfinding out causing factors of broken of society order by the capitalistic and secularistic of Western culture penetration. As an example, by identifying the local wisdom of J avanese, Bataknese, Minang, the Bugis, and Balinese can be used as references to figure a dignified nation as recommended by Benedict Anderson in the form of country.

This articletryto createa dignified Indonesian nation in thecontextofJ avanese culture of thought by trying to explore the local wisdom covering identification of the foretime local J avanese ethnic wisdom, the broken down of society order due to Western culture penetration, and cultural strategy in the purpose of developing a dignified Indonesia.

\section{The Javanese Local Wisdom}

According to the philosophy of cakramanggilingan, history of human life resembles the rotation of the wheel (mubenge jagad), which means every history would happen in today's life or in the future. Today's history, in fact, is the repetition of every past history, or today's history will be repeated in the future life. Based on that philosophy, the today's crisis time in Indonesia is the reccurence of the past crisis.

The crisis era terminology in the discourse of J avanese culture is addressed as kalabendu which means theera when peopleget in tempest or calamity (pageblug) due to God's curse through Bethara Kala. Kalabendu has several indicators as moral degradation among functionaries and societies. This condition has caused the spread of corruptions, prostitution practices and criminals as well as the occurance of natural disasters. According to Soemarsaid Moertono, kalabendu occurred dueto the Kingorberaucrats that supposed to give exemplary, protection, tranquility and social welfare instead creating misery to society (Moertono, 1985: 56).

The term kalabendu pertaining authorities party has failed to organize the administration. The King as ruling party did not play his role as mediator between community and God, since wahyu-keprabon (revelation) as the legitimation 
have been out of the King's inner soul and found a new soul in the name of Ratu Adil (Fair Queens) to exterminate every crime and would bring prosperity to the community (Kartodirdjo, 1986: 88-89).

According to Benedict Anderson (1972: 3-4), the J avanese rule has following characteristics: (1) the power is not something theoretical except real. The power is God's energy. (2) the power is homogene with similar type and sources; (3) the magnitude of power in the universe is constant and substantially static, which means there will never increase or decrease. However, for every individual who is trying to accumulate the power into soul, therefore it may increase or decrease or even disappear if the soul is broken.

The requirements needed in order to compile the power are by providing a good soul by scarifice (matiraga), for instance, by meditation in the cave or forrest, fasting (suda dhahar klawan guling), meditation in a room without any lighting (patigeni), being vegetarian (ngrowot), bathing in the river (kungkum), meditation to entertain yourself (pasa mendhem), being silence (tapa ngrame), prohibition of sex and so forth (Krisnandi, 1998). Based on J ava tradition, those who are succeed to collect the power (God's energy) will receive wahyu keprabon (revelation) as legitimation sebagai leadership legitimasi in the form of a bright blue or green or white light called wahyu, pulung or ndaru (Krisnandi, 1998). They who have received wahyu-keprabon assumed that authority (position) is a mandate from God, and it is a sacred duty from God with the purpose to crease social welfare, that people can see and love it as an honest, fair and credible administration (Sudjarwadi, 2010). With the respect to the situation, Ki Hajar Dewantara gave an advice to the leaders in carrying out their duties by slogan ing ngarsa sun tuladha, ing madya mbangun karsa, tutwuri handayani, which means a leader (teacher) will give examplaries in front of the subordinates (students), will motivatethesubordinates or encouragethem for high performance and creativity and will give support and opportunity for the subordinates to be independent (Poesponegoro dan Notosusanto: 1984: 246). Prince Samber Nyawa (Mangkunegara I) gave an advice about Tri Dharma carried by a leader in performing his duties as follows: (1) rumongso melu handarbeni (sense of belonging), rumongso melu hangrungkebi (sense of responsibility) dan mulat sariro hangaroso wani (introspective and brave) (Rukmana, 1987:203).

According to the concept of God-King, the J avanese Kings have supernatural power that identically similar to God's supranatural power. Therefore, they were addressed as Gusti kang mangejawantah, which means God who ruling over the earth that unite the people (Manunggaling kawula-Gusti) (Sudjarwadi, 2011). The King mentioned has God's character inside that make he has absolute power (tan-winates). What has been said by the King (sabda) is a command (titah), it is errefutable and should be done by his people. This is because the King's command is identically similar with God's will (titah Gusti) that should befulfilled by the people( Timoer, 1989). For those who break the command of the King, are considered subversive (mbalelo) and intercepted to a war (dipapag perang) (Moedjanto, 1987: 1964). 
According to Kyai Yasadipura I, the ideal J avanese king has the character called Asta Brata (eight wisdoms) consists of: (1) having unlimitedly generous as God Endra (Dewa Endra); (2) having ability to eradicate every wickedness of God Yama (Dewa Yama); (3) having ability to govern wisely and invite the people to have sacred live as God Surya (Dewa Surya); (4) having a good sense of compassion toward people and also toward his enemies as God Candra (Dewa Candra); (5) having ability to brilliantly think and rigorous as God Bayu (Dewa Bayu); (6) pleased to provide clothes, foods, shelter and even entertainment for people as God Kuwera (Dewa Kuwera); (7) having ability to solve any problems as difficult as God Varuna (Dewa Varuna); (8) upholding truth and justice and also have passion to eradicate all evil as God Brama (Dewa Brama) (Moertono, 1985: 52).

The purpose of life according to Eastern philosophy is struggling to seek the release of lust that shackles our soul in the path to eternal life in heaven. They turn away from this world and focus on the eternal life in the hereafter (Van Peursen, 1978: 105-113). The philosophy does not view the world as an object to be researched or source of exploration to enhance the social welfare, but it sees the world as something shackles the soul in the purpose to pilgrimage toward sangkan paraning urip (the purpose afterlife), so that people will not be tempted with cumloroting kencana (worldly possessions), gemerincinge ringgit (money), or sumilaking jarit (sexual desire) (Sudjawardi, 2011). They interpret the life as something temporary (mampir ngombe), and should be used wisely to do something in virtue for afterlife puspose in heaven. They assume that life prosperity is not about material possession (worldly possessions), but rather determined by how is a person ability could release from worldly ties.

J avanese people toke care of their life by implementing the balance concept of life (harmony) between jagad gede (macro cosmos) and jagad cilik (micro cosmos). With respect to the condition mentioned earlier, they have to memayuhayuning bawana langgeng (attempt to have prosperity afterlife), which means they have to beautify their worldly life by preserving the nature as well as being environmentally friendly (Sudjawardi, 2011)). This is because nature is the source of living, so that, it becomes proper to be preserved as well as maintain the ecosystem and biodiversity. If human being destroyed the natural environment, cosmos rhythmic will be disrupted so it does not create harmonious relations between macro and micro cosmos, and natural disaster will occur as the consequence of this situation.

\section{Western Culture Penetration}

Western philosophyassumed that theworld isaresearch objectand exploration object for human prosperity. We can see that this Western philosophy has shifted the human welfare standard from spiritual well-being (Eastern philosophy) to physical well-being through the exploration (mastery of worldly possessions). This condition has opened such an opportunity toward people to destroy natural 
preservation, greedy to theenvironment, so that the cosmos rhytmis disrupted and causing natural disaster, eventually. In order to mastery in worldly possessions, it opens the opportunity of morality degradation toward Indonesian nation as well as the opportunity of a new corruption growth on every aspect of living.

The history has writer, the meeting of one culture with another have created the sophisticated cultural development. The growth of Western Europe culture, for instance, is the result of the assembly between Islamic cultures in the Crusade. The emergence of Renaissance in Northen Italy is as the result of the assembly of Classical Greek cultures. In Indonesia, the assembly of the original Indonesian culture and Hinduism, Budhism, Indian as well as Islam (in Eastern cultures) have resulted high quality syncretism. Indian nation, who is superior in organizational system as in dialogue pertaining culture with other tribes in the archipelago, is bringing out Hinduism and Budhism kingdoms. Monumental buildings as Borobudur, Prambanan, Demak Mosque, and the architecture of local kingdoms with Islamic culture are part of the products of cultural dialogue. This is showing the great advantage as well as the advancement as the result of cultural meetings. According to Soedjatmoko, cultural vitality of one nation in the dialog with another culture is proven by the ability to be stimulated of external influences towards a greater creativity. Besides, vitality of one nation is reflected from the courage to run some experiments and try a new path that is not yet included in the culture of origin (Soedjatmoko, 1988: 46-47). Then, how does the archipelago culture do a dialogue with the Western culture?

Portugese occupation upon Malacca (1511) had opened an opportunity to this nation to take the fairway archipelago by takingover Sunda Kelapa harbor in 1527 (Simbolon, 1995: 31). Yet, Demak Kingdom that was expected to stem Western colonialism in the archipelago even getting weaker, then faded as the consequence of succession among the Kings. European power that comes next is the Netherlands which is much stronger compared to Portugese and Spanish. VOC (the Dutch) came first in the archipelago (Ujung Kulon, Banten) on J une $22^{\text {nd }}, 1596$ with the purpose of trading, but subsequently occupying some significant port cities in the archipelago trading route as Malacca (1641), Batavia (1642), Moluccas (1655), Minahasa (1658), Palembang (1662), Gorontalo (1677), Mataram (1667), Macassar (1669) (Simbolon, 1995: 47-48). Furthermore, the Dutch did not satisfied for just do trading in the archipelago per se. Later on, the archipelago was created as their colony until the arrival of J apanese troops in 1942.

The Dutch colonial period in the archipelago was the penetration period of Western culture toward the archipelago's culture. In the encounter with Western culture, the profane archipelago culture loss of adaptive and crative vitalities in the dialogue with the secular Western culture. Cultural value system of domestic and social institutions has broken in facing the wave of Western culture (Kartodirdjo, 1971: 66=67). Along with the Dutch presence in the archipelago, there was an internal business among local Kings pertaining succession of war in suggesting that traditional authority legitimacy is being questioned (Ali, 1985: 44-45). Some throne competitors (usurpator) claimed that they are the Fair 
Queens who has obtained God's blessing to save the people from injustice and wickedness, and will establish a peaceful and prosperous administration. The history of local revolts in J ava was not only happened in the era of colonial but also in the era of post-independence. These revolts fetured leaders symbolized by sense of disappointment and despair of the political elite, in order to persuade their followers to revolt in the name of Fair Queens (Soedjatmoko, 1988: 81). It seems that the political elite were no longer gathering power of God by sacrifice (bermatiraga) or sanctify yourself, but they were claiming that the revelation (wahyu keprabon) are "on their pocket" at the moment.

Such condition are exacerbated by the penetration of the secular Western culture that offer worldly pleasures and greed of the capitalist in the purpose of exploiting the world as well as destroying the society order that had caused moral crisis when people were entering the dark ages (kalatidha). This was occurred when the Dutch political and economic power were embedded powerfully in J ava, especially in the 1870's. In accordance with that situation, Raden Ngabehi ronggowarsito desperately pictured kalathida ages happened at the moment with a series of poems in the following Serat Kalatida:

“Mangkya darajating praja/ Kawuryan wus sunya ruri/ Rurah pangrehing ngukara/ Karana tanpa palupi/ Ponang parameng kawi/ Kawelwiting tyas maladhung/ Kungas kassudranira/ Tidem tandaning dumadi/ Ardayeng rat dening karoban rubeda.//Ratune-ratu utama/ Patihe patih linuwih/ Pranayaka tyas raharja/ Panekare becik-becik/ Parandene tan dadi/ Paliasing kala bendu.//Amenangi zaman edan/ Ewuh ayahing pambudi/ Melu edan nora tahan/ Yen tan melu anglakoni/ Boya kaduman melik/ Kaliren wekasanipun....

Anderson translated the freely poem as follows:

"The degree of state/ seems quiet/ mastery of sentence is back/ since thelack of role models/ as for the major poet/ twisted by a heart full of worldly love/ spreading of the degree of humility/ no sign of life / feels that the world is full of misfortune.// King of the primary King/ the duke of the capable duke/ guards with good hearted/ take care of His security/ nevertheless they do not become/ refusing Kala's wrath...// Experiencing the mad ages/ difficult in trying to use mind/ want to go insane but cannot bear it/ (but) if they do not follow the flow/ will they inherit the ownership/ being starving eventually... //"'Soedjatmoko, 1988).

According to Anderson, the poem depicts the collapse of J avanese Kings. He argued that, based in traditional J ava ways of thingking, when the King of the primary King (Ratune-ratu utama), the governor loves the truth (Patihe patih linuwih), so that cosmos and the society should in the safe condition, peaceful. Meanwhile, as shown in the poem, the fact shows precisely the opposite. One awesome word parandene (nevertheless) expresses profound despair of Raden Ngabehi Ronggowarsito toward the tradition. Realizing that the old ideas about 
the natural world were no longer considered valid, the rhytm of cosmos became so erratic and the power of Javanese weakened. According to Anderson, an old poet who was just waiting for his death, in 1873, talked about his concerns pertaining this period that considered as period of darkness which is endless. Nonetheless, there is an open space to criticize the poem contextually. Raden Ngabehi Ronggowarsito as poet of the palace was usually rubbing the King's feet (ngelus-elus tungkake raja) (Toer, 1995: 39) in order to flatter the kindess of the King and the royal officials. (Ratune-ratu utama/ Patihe patih linuwih/ Pranayaka tyas raharja/ Panekare becik-becik), for all their needs met the King (Krisnandi, 2007: 33). Do not you think that moral decline is a sign of the King's failure and upon his leadership in organizing the government?

However, Sartono Kartodirdjo was more optimistic in facing kalabendu. He argues that kalabendu is a sign of Fair Queens coming sent by God to save the world that has been damaged due to human sins (Kartodirdjo, 1971: 14). The offers of worldly pleasures from the secular Western culture, including the greed of the capitalists, are the consequences of the coming kalabendu. According to Michael Addas, the J ava community was hoping of the coming of Fair Queens to rejuvenate the universe since kalabendu is the period showing that the univers grew older (Addas. 1988: 56). Sunan Paku Buwana IX has produced literature work entitled Wulang Reh, with the purpose to give exemplary to the public pertaining on how to behave in a good way both physically and mind as a thrust toward the negative values of Western culture (Suradi, 1988: 38).

\section{Cultural Strategy in Building a Dignified Indonesia}

\section{National Reconsiliation}

Basic J avanese culture rationale has justified the crisis period in Indonesia at the moment is caused by the historical sins in the past. According to Permadi SH, J avanese tradition hasinherited ruwatan in mass (national repentance). Through the national repentance, God forgives all historical inherited sins for instance assassination and persecution or even character assassination in the relation with the Madium incident in 1948, tragedy of G.30.Sin 1965, Tanjung Priokincident, or another incident. As the reaction of repentance, courage is required to completely resolve the inherited problems. If it was proven that someone is involved with PKI (Communist party) in the Madiun incident in 1948 or G.30.S tragedy in1965, should be legally resolved. Likewise, if Soeharto was proven as intellectual actor in the murder G.30.S tragedy in 1965 which spread into regions, and as the person who is responsible toward number of 9.957 political prisoners to Konsentrasi Buru Camp for 10 years (1969-1979) without any judicial processes, he should be legally resolved (Krisnandi, 2001:.1985).

President of the Republic of Indonesia, Abdurahman Wahid, said that reformation and democratization run as it should be, so that (provision) Tap MPRS No. XXV/MPRS/ 1966 pertaining to the prohibition against PKI and its 
mass organization of Marxis-Leninis doctrinemust be abolished. Do notyou think that prohibit people's mind (Marxis-Leninis) is violating human rights as well as contradicting with the spirit of reformation and democracy? If the provision is maintained, which means the implementation of democracy in Indonesia, minus-PKI, there is no minuses in democracy. Democracy recognizes that every citizen has equal rights. If people who are anti-PKI were given political freedom, therefore people who are part of PKI should be treated the same way. This is discriminatory, even though there is no discrimination in democracy. People in PKI are also Indonesian citizens, in relovlutionary period, together they shoulder to shoulder against the colonial of Dutch, and in the post-revolution they fought to defend the oppressed peasants and labours. After all the issues were legally resolved, and then taken to the National Reconsiliation in order to forgive the guilt. It is not the attitude of forgiveness as an act of commendable, is it? After that, this nation will not get burden of sin and can look ahead to build a dignified Indonesia by implementing the clean, honest, fair and prestigious administration system.

\section{The Clean, Honest, Fair, and Prestigious Administration}

The implementation of genuine and sincere National Reconsiliation has brought inner purity as principal to build a dignified Indonesia with sacred intention to organize the clean, honest, fair and prestigious administration. Through lawsupremeenforcement and peoplesupervision, theproses of employee recruitment, job promotion or job description was conducted professionally, honest, fair and clean of coalision and corruption acts. The leaders (officers) and employees, other than upholding the spirit of professionalism and demonstrate the optimal performance, they have to close with the God's revelation in order to ge a leader because of money and abuse his position for his own, group or party's benefit. Rather they work in the guidance of God's verses for social welfare, so that the implementation of the administration will be good in the eyes as well as being loved by the people. So that, this could be a nation called wahyawibawa graha (Soedjawardi, 2011).

\section{Establish the Law Supreme}

The law supreme in this country is pretty weak and concern. Laws have been traded that makes people difficult to find a sense of justice and truthfulness. Laws enforcement officials have defended those who pay them as defender of justice. It is as if thelawin this country is blunt when faced corruption issues. Nonetheless, it will reveal sharp as a razor when faced with an old widow who stole a chocolate, or the other people who do not have power and money, or toward anyone who would expose the corruption. The case of Bank Century which is considered jeopardize to the government was left behind. The people in Indonesia are pleased to engaged 
in holy war, jihad fi sabilillah, to deal with the law enforcement officials who get involve with the corruption who are considered as the enemies both of God and the people. The people, for instance, can escort and push the judges in each of the courts. People have succeeded release Prita, haven't they? Then why would they not continue such kind of holy war, jihad?

\section{The Cultural Corruption Eradication Movement}

Corruption as social disease that has plagued the Indonesian nation is now in the "entrenched" stage with the spread to the whole aspects of life. To cure this croniccorruption disease, weneed to uphold thelawsupremeby givingpunishment towar the corruptors and sentence the heavy weight corruptors with death penalty as a "reward". Thecorruption eradication can bedonethrough cultural movements within the family, neighbours, as well as the working environment (office). We can take an example as the position for the unpaid leaders of RT (neighbourhood) or RW (pillars of the citizens) has given an opportunity to corrupt by doing extortion in the process of implementing the administration matters. As solution, the government should allocate fund for salaries/ honorarium. Although they are paid, but in fact, corruption is still underway. This condition can be prevented by not following the flow of charges even in a small amount. Families or housewives have the ability to against corruption by educating their children to be honest, keep truthful, and do something right. When the husband's income is not really support to have a lavish lifestyle, then the wives should be able to adjust with the situation. Education within family that instill anti-corruption will become the important key to eradicate the corruption right from its roots.

The culture that allows deviations let the corruption grow in the community. Cheating on a small thing can slowly create a corruption within the community. In education, there are symptoms of being unfair such as cheating in examination or informing the national final examination questions. We can take an example of the administration officials urged the examination supervisor not to strickly supervise the examination participants. Another example is that techers, students or even the parents seem understand and allow the students to cheat on exam due to gain formal achievements. But in fact, all those things mentioned above would be the origin of corruption later on. Some educators are pursuing the instant achievement by concerning more with the results rather than the process. This condition has sacrified the crucial values as being honest or truthfulness. These are the seed of corruption. When the corruption is being entrenched in the society as well as bureaucracy, political movement and law will never be enough to against it. As the consequences of that, we need a systematic movement through education within the families. Women, families, and educational institutions from pre-school to higher education have to instill values of anti-corruption from the beginning of the education as character building, discipline and obedience.

The role of print media as well as electronic media are very helpful in eradicate the corruption to its roots. Through the media exposures, in both printed and 
electronic media, there is an invitation for holy war (jihad fi sabilillah) toward corruption astheenemies of Godand thesociety. Theinvitation forholywar(jihadfi sabilillah) iscreated in many ways such asin theform of soap opera, advertisement, interactive dialogue, and entertainment as well as arts performances. These efforts should be continuously advertised to create anti-corruption image among the community. The society realizes that corruption, collusion, and nepotism are disgraceful, unlawful, enemy of the people surroundings and God's wrath. This image lives within the heart of people and melt with their identity, so that can be used as tools to eradicate the corruption to its roots.

\section{Embedding the Culture of Being Ashamed}

Indonesia has lost its "treasure" at the moment in the form of being shame (Sugionao, 2011). With the loss of shame, humans do not ashame of doing something improper. Young people are not ashame of kissing in front of crowds. Husband and wife are no longer being ashamed of having affairs. Students do not feel embarrassed to do pre-marital sexual relations. It is the same with the leaders who are not embarrassed to keep on their position even have done many mistakes or been prisoned. The member of the council in the district, province, or headquarter are not ashamed of using government's money. Likewise, the executive officers of the village up to the headquarter are not ashamed to use the cash from regional cash, regional operation support, operational assistance for school, APBD (State Budget Revenue Expenditure) and other subsidies. They do not feel guilty or innocent by doing such infraction. In accordance with the situation, Ebiet G. Ade, a singer, has insinuated the administration officers who have misconducted in his song "Berita kepada kawan" (news to a friend) through his verse "always be wrong and proud of his sins.. as the consequences, God is getting tired of our behavior or the nature is getting reluctant to be our friends".

If the official or leaders and even its people have no shame, destruction of the country is just a matter of time. Before the total destruction has not occurred, all elements of ths country, especially the "sane" ones, should be called for the holy war (jihad fi sabilillah) by learning, understanding, awareness and appreciation the culture of being shame toward the improper act within family, environment, society, as well as work environment. The culture of being ashamed of doing something improper is a highly valuable capital to build a dignified Indonesia, instead of good and positive things; humans should not be ashamed to do it.

\section{Love the Local Product and Proud of being Part of Indonesian Nation}

The globalization era is marked by the advancement of technology, communication and information has eroded the personality of Indonesian nantion. Nowadays, young generation prefers Western music that is considered as modern rather than traditional music that is considered old. Indonesian 
children love to play imported robot, "rifle", "cars" and welcome to linger in front of the computer playing games instead of playing the traditional games such as gobaksodor, egrang, benthic, gasing and other traditional games that considered old fashioned. We are more proud of visiting foreign restaurant or supermarkets that are considered prestige rather than visiting a traditional one or shopping at the traditional market. Besides, Indonesian people prefer to choose imported product as clothing, shoes, cosmetics or goods for the sake of prestige rather than choosing the local one for it considered less fashionable or low quality. For automotiveproducts, thereare J apaneseproducts haveflooded and theymonopoly the market of this country. Likewise, foreign films have existed in Indonesia while the local film industry is just like strangers in their own country.

Thisphenomenonindicatestheongoingculturalandeconomicalcolonialization of foreign capitalism in Indonesia. As young nations, we immediately called to build a dignified Indonesia by developing the feeling of loving local products that may resulting the proud feeling of being Indonesian. Do not let the foreing capitalism in the form of products control the country. It should be rejected by inflame the cultural movements reject the negative values of foreign cultures as opposed to the personality of Indonesia and against the foreign products that are colonizing our country. Do not let the foreign capitalism products as cars and motorcycle full on the street, let us assemble national cars or motorcycle not only as nation prestige but also as an effort to stop colonialism in the form of foreign economic capitalism toward economic independence for the nation. We have to be ashamed to Malaysia that already has produced local cars, Proton. Let us build an automotive industry, film industry and other industries so that we can be the host in our own country and reject imported product from outside the country. Let us reject all kind of foreign culture that has eroded Indonesian identity within the nation. Let us surge cultural movement in order to build the feeling of loving local products (swadeshi) agar tercipta kemandirian ekonomi bangsa (Husain, 1978: 437). Let us cultivate cultural values of loving domestic products and being proud of Indonesian nation that can be started from the family, society and work environment. The role of parents, teachers, scholars and leaders (both formal and non-formal) as well as role of media both printed and electronic arevery important in order to instill the awareness amongyoung students and subordinates to do the real action in loving local product and being proud to be a dignified Indonesia.

\section{Development of Science and Technology with Archipelago Conceptual}

The role of science and technology in the society is ambiguous, on the one hand it leads to the improvement quality of life, and on the other hand it aims to destroy human dignity. According to Mohandas K. Gandhy, science and technology developments in recent years has risen ethical issues associated with abusement of authority of scienceand technology which harmful to society, so that it is needed to establish a clear ethical stance and assertive in the development 
of science and technology (Poespowardojo, 2003: 1). In accordance with that, H.A.R. Tilaar has offered eight principles of science and technology development based on moral values of politeness and humanitarian law as follows:

Table 12.1 Eight Principles of Science and Technology Development toward a Dignified Nation

\begin{tabular}{|c|c|c|c|c|}
\hline \multirow{2}{*}{$\begin{array}{l}\text { Develop- } \\
\text { ment Prin- } \\
\text { ciples }\end{array}$} & \multicolumn{3}{|c|}{ Moral Values } & \multirow{2}{*}{$\begin{array}{l}\text { Development Path- } \\
\text { way }\end{array}$} \\
\hline & Politeness & Law & Human- & \\
\hline $\begin{array}{l}\text { Freedom and } \\
\text { academic re- } \\
\text { sponsibility }\end{array}$ & $\begin{array}{l}\text { - Apreciate the clash } \\
\text { of ideas } \\
\text { - Freedom of speech }\end{array}$ & $\begin{array}{l}\text { - Guaranteed by the } \\
\text { law as long as not } \\
\text { incite, not attact } \\
\text { people and not } \\
\text { doina immoral }\end{array}$ & \multirow{7}{*}{$\begin{array}{l}\text { D e v o te d } \\
\text { to human } \\
\text { dignity and } \\
\text { survival of } \\
\text { human's life } \\
\text { based on } \\
\text { Pancasila }\end{array}$} & $\begin{array}{l}\text { Building cultural research } \\
\text { institutions and universi- } \\
\text { ties }\end{array}$ \\
\hline $\begin{array}{l}\text { Love original- } \\
\text { ity }\end{array}$ & $\begin{array}{l}\text { - Against plagiarism in } \\
\text { science and technol- } \\
\text { ogy invention } \\
\text { - Against counterfeit- } \\
\text { ing academic de- } \\
\text { arees }\end{array}$ & $\begin{array}{l}\text { - Against the usage } \\
\text { of fake academic } \\
\text { degree akademik } \\
\text { palsu. }\end{array}$ & & $\begin{array}{l}\text { The existence of laws and } \\
\text { regulations that prohibit } \\
\text { trading of academic de- } \\
\text { gree by heavy sentence. }\end{array}$ \\
\hline $\begin{array}{l}\text { Mentoring } \\
\text { task in the } \\
\text { process in } \\
\text { science and } \\
\text { technology } \\
\text { develooment }\end{array}$ & $\begin{array}{l}\text { - Guiding students } \\
\text { young researchers } \\
\text { - - A p p r e c i a t - } \\
\text { ing the credibility of } \\
\text { peers }\end{array}$ & & & $\begin{array}{l}\text { The existence of coopera- } \\
\text { tion between scholars and } \\
\text { researchers in developing } \\
\text { science and technology. }\end{array}$ \\
\hline $\begin{array}{l}\text { Te a ching } \\
\text { responsibil- } \\
\text { ity/research/ } \\
\text { community } \\
\text { service }\end{array}$ & $\begin{array}{l}\text {-The main duty of a } \\
\text { lecturer/researcher is } \\
\text { teaching, researching } \\
\text { and not in the civil ser- } \\
\text { vice or other activities. }\end{array}$ & & & $\begin{array}{l}\text { Enhance the appreciation/ } \\
\text { lecturer's status }\end{array}$ \\
\hline $\begin{array}{ll}\text { Finding } & \text { new } \\
\text { things } & (\mathrm{Re}- \\
\text { search) } & \\
\end{array}$ & $\begin{array}{l}\text {-Appreciate the cre- } \\
\text { ative and innovative } \\
\text { researchers }\end{array}$ & & & $\begin{array}{l}\text { Enhance the appreciation } \\
\text { and status of the research- } \\
\text { ers }\end{array}$ \\
\hline $\begin{array}{l}\text { Finding the } \\
\text { truth } \\
\text { Science pub- }\end{array}$ & $\begin{array}{l}\text {-Never manipulate the } \\
\text { data either for personal } \\
\text { or political advantages. }\end{array}$ & $\begin{array}{l}\text { - Recognition of } \\
\text { IPR/patents } \\
\text { - The punishment }\end{array}$ & & $\begin{array}{l}\text { Depoliticization and higher } \\
\text { education de-corporatiza- } \\
\text { tion }\end{array}$ \\
\hline lication & $\begin{array}{l}\text { - Scientific honesty } \\
\text { It is not just disseminat- } \\
\text { ing the information but } \\
\text { also for the science and } \\
\text { technology develop- } \\
\text { ment }\end{array}$ & $\begin{array}{l}\text { for the piracy of } \\
\text { science and tech- } \\
\text { nology }\end{array}$ & & $\begin{array}{l}\text { - Aworthawardforscien- } \\
\text { tific publications, authors } \\
\text { and the inventor of sci- } \\
\text { ence and technology } \\
\text { - Expand scien- } \\
\text { tific journals and scholarly } \\
\text { books }\end{array}$ \\
\hline
\end{tabular}


I.G. KRISNADI

"Imagine Yourself" Being a Dignified Nation: A Preliminary Assesment

\begin{tabular}{|l|l|l|l|l|}
\hline $\begin{array}{l}\text { Devoted to } \\
\text { the progress } \\
\text { of the society } \\
\text { and humanity }\end{array}$ & $\begin{array}{l}\text { Science and technology } \\
\text { that have advanced the }\end{array}$ & $\begin{array}{l}\text { Prohibit research } \\
\text { that is not humane } \\
\text { society and humanity. } \\
\text { like as clo-ning, } \\
\text { weapons of } \\
\text { mass destruc- } \\
\text { tion. }\end{array}$ & & $\begin{array}{l}\text { Avoiding Mc } \\
\text { Donaldization in higher } \\
\text { education }\end{array}$ \\
\hline
\end{tabular}

\section{Build Social Ethics based on Religion}

The anti-corruption law, the establishment of the commission, the legal institutions and political policies are found to be able to uproot the culture of curroption that has been ingrained. The low of ethics, loss of commitment toward culture without violence and the respect of life have led to corruption, collusion and nepotism among administration officers as well as many practices of demoralization and dehumanization. Religion has lost its ability to respond creatively to social change. It often shows the face of fundamentalistic. In other words, the difficulty in addressing social changed can cause the religion loses its influence and relevance.

At the same time, there was a strong awareness that life cannot be allowed to grow wildly with no guidance from the religion. Therefore, religion will play more effective and widespread as well as have sources of spiritual, intellectual and ethical to provide answers, solution and the appropriate respons to the contemporary issues. If religion has failed in the new mission, with profit purposes, to give proper gidence (proper guide) as well as a holistic action plan, so that the spiritual and moral vacuum will be filled by "new religions" in the face of mysticism movement, terrorism, cult sect and RAS (tribes, peoples, races and between classes). Moral-spiritual consciousness transcendent the personal loyalties, ratial and national ethics that are believed to be more effective than the legal institution in suppressing corruption or various form of injustice. Religion is not only owned by certain elites that limitly discuss about the "sky" (higher level issues) per se but also owned by the community who can discuss about "earth" as we stand (Luthfi, 2003:2 ).

Therefore, our country should open up some spaces fot the expansion of faith based ethics and spiritual values into the business world, profession, industry, educational institutions, media, politics as well as international relations. This Ethics has provided moral basis for individual and global for better order. Social ethics that will be formed is not a new religion or rival of the former religion that has existed for centuries. Social ethics is not an ideology, syncretism or the unificantion of all religions, nor the domination of one religion over another. Social ethics will make the religion and belief as a source of values as attached standar ethics. That is based on the consideration of the similarity of the religious pertaining love, virtue, justice and opposes any kind of violence. 


\section{Conclusion}

The philosophy of Cakra Manggilingan sees history as something that is repeated. Some event in the past will be reoccurred in the present; meanwhile, current event will recur in the future. In Javanese tradition, the crisis that is happening at the moment is something called kalabendu that happened in the past. Finding the Javanese ethnic and identifying causal factors of kalabendu in the past can be used as referential cultural strategy in the purpose to build a dignified Indonesia.

Javanese local wisdom suggests the emergence of kalabendu as the curse of God for people's sins. Besides, the J avanese tradition is the hint of national's ruwatan as the request to God in order to obtain purity in mind to end kalabendu. National reconciliation is a main choice in the making of cultural strategy to build a dignified Indonesia. The implementation of administration which honest, clean, fair, transparent and prestigious, in line with law enforcement, cultural movement to eradicate corruption from its roots, and the cultural development ashamed of misconduct among family, community, workplace, and in national life as well as the state, developing sense of being pride toward Indonesian nation and let people love the local product, the development of science and technology vision of humanity, and build a social ethos based on religion are believed as the end of the crisis as well as able to build a dignified Indonesia. 


\section{REFERENCES}

Abdullah, T. (2001). Nasionalisme\&Sejarah. Bandung: SatyaHistorikaAddas, M. (1988). Ratu Adil, Tokoh dan Gerakan Milenarian Menentang Kolonialisme Eropa. J akarta, Rajawali.Anderson Benedict R.O.G; 1972. Gagasan Tentang Kekuasaan dalam Kebudayaan Jawa. Unknown city and publisher.

Anderson, B. (2006). I magined Communities: Reflections on the Origin and Spread of Nationalism, New Edition. New York: Verso.

Fachry Ali, 1986. Refleksi Paham “Kekuasaan J awa” dalam Indonesia Modern. J akarta: Gramedia.

Husain, S.A. (1978). Gandhi Sebuah Otobiografi: Kisah EksperimenEksperimenku dalam Mencari Kebenaran. J akarta: Sinar Harapan.

J awa Pos, Radar J ember, Minggu 21 November. Profesor I.C. Sudjarwadi, Seimbang Unsur Yin dan Yang.

J awa Pos, Minggu 24 April 2011, Sudiono, Teologi Malu.

Kompas, Kamis 21 April 2011, Bukti Baru Antasari: Antasari Sedang Tangani Laporan Dugaan Kasus-kasus Besar.

Kompas, Minggu 24 April 2011. Perangi Lewat Keluarga.

Kohn, H. (1984). Nasionalisme, Arti dan Sejarahnya. Jakarta: Erlangga.

Krisnadi, IG., "Wahyu Kraton Miturut Kabudayan J awa," dalam J aya Baya No. 32, 12 April 1998.

-------, Mbok Randha KenapaingWengi Iki Sliramu Nlilir, dalam majalah Dharma Wanita XV, 1993, Universitas J ember.

-------, Tahanan Politik Pulau Buru (1969-1979) (J akarta: LP3ES, 2001).

--------, Pujangga Kraton: Mbangun Sastra, Marsudi Basa (Makalah Proceeding), Kongres Bahasa J awa IV di Semarang, Jawa Tengah. 10-14 September 2006.

-------, 2007. Historiografi Indonesia Tradisional (Buku Ajar). Fakultas Sastra, J urusan Sejarah, Universitas J ember, 2007.

Luthfi, M. (2003). Agama dan Etika Sosial (makalah), dipresentasikan dalam Semiloka Etika Kehidupan Berbangsa oleh Kementerian Kebudayaan dan Pariwisata, Hotel Mega AnggrekJ J. Arjuna Selatan No.4, Palmerah, J akarta Barat.

Moedjanto, G. (1987). Konsep Kekuasaan J awa, Penerapannya oleh Raja-Raja Mataram. Yogyakarta: Kanisius. 
Moertono, S. (1985). Negara dan Usaha Bina-Negara Di J awa Masa Lampau; Studi Tentang Masa Mataram II, Abad XVI Sampai XIX. Jakarta, Yayasan Obor Indonesia.

Peursen Van, C.A. (1978). Orientasi di Alam Filsafat. Diterjemahkan Dick Hartoko. J akarta: Penerbit PT Gramedia.

Poesponegoro, M.J dan Notosusanto. (1984). Sejarah Nasional Indonesia V . J akarta: PN Balai Pustaka.

Poespowardojo,S. (2003). Etika Keilmuan (makalah), dipresentasikan dalam Semiloka Etika Kehidupan Berbangsa yang diselenggarakan Kementerian Kebudayaan dan Pariwisata, Hotel Mega Anggrek Jl. Arjuna Selatan No.4, Palmerah, J akarta Barat pada 16-18 Desember 2003.

Renan, E. (1994). Apakah Bangsa Itu? (Qu'est ce qu'une nation?). Terjemahan Prof. Mr. Sunario. Bandung: Penerbit Alumni.

Rukmana, H. (1987). Butir-Butir Budaya Jawa: Hanggayuh Kasampurnaning Hurip Berbudi Bawaleksana Ngudi Sejatining Becik . Unknown city and publisher.

Sartono Kartodirdjo, 1971. “Lembaran Sedjarah Indonesia No. 7; Messianisme dan Millenarisme dalam Sejarah Indonesia." J ogjakarta, Seksi Penelitian Djurusan Sedjarah Fakultas Sastra dan Kebudajaan UGM.

------..(1986). Ungkapan-Ungkapan Filsafat Sejarah Barat dan Timur. J akarta: Penerbit PT Gramedia.

Simbolon, P.T. (1995). Akar-akar Kebangsaan Indonesia. J akarta: Grasindo.

Soedjatmoko. (1988). Etika Pembebasan: Pilihan Karangan tentang: Agama, Kebudayaan, Sejarah dan Ilmu Pengetahuan. J akarta: LP3ES, Cetakan III.

Sukarno. (1964). Dibawah Bendera Revolusi Jilid I, Cetakan Ketiga (Tanpa kota terbit, Panitia Penerbit Dibawah Bendera Revolusi.

Suradi, HP; (1988). Pengungkapan Isi dan Latar Belakang Serat Wulang Reh. J akarta: Depdikbud. Dirjen Kebudayaan Direktorat Sejarah dan Nilai Tradisional..

Toer, P.A. (1995). Nyanyi Sunyi Seorang Bisu: Catatan-catatan dari Pulau Buru. Kuala Lumpur: Wira Karya.

Tilaar, H.A.R., Etika Keilmuan: Pengembangannya dalam Dunia Akademik di Indonesia (makalah), dipresentasikan dalam Semiloka Etika Kehidupan Berbangsa, oleh Kementerian Kebudayaan dan Pariwisata, Hotel Mega Anggrek Jl. Arjuna Selatan No.4, Palmerah, Jakarta Barat pada 16-18 Desember 2003.

Wawancara dengan I.C. Sudjarwadi, 25 April 2011. 
I.G. KRISNADI

"Imagine Yourself" Being a Dignified Nation: A Preliminary Assesment 